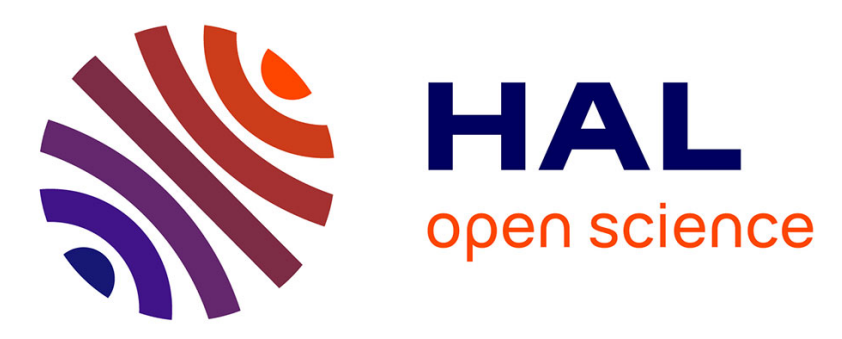

\title{
Detection of titanium nanoparticles in the hair shafts of a patient with frontal fibrosing alopecia
}

\author{
F. Brunet-Possenti, L. Deschamps, H. Colboc, A. Somogyi, K. Medjoubi, D.
} Bazin, V. Descamps

\section{- To cite this version:}

F. Brunet-Possenti, L. Deschamps, H. Colboc, A. Somogyi, K. Medjoubi, et al.. Detection of titanium nanoparticles in the hair shafts of a patient with frontal fibrosing alopecia. Journal of the European Academy of Dermatology and Venereology, 2018, 32 (12), pp.e442-e443. 10.1111/jdv.14967 . hal02160743

\section{HAL Id: hal-02160743 \\ https://hal.sorbonne-universite.fr/hal-02160743}

Submitted on 24 Feb 2021

HAL is a multi-disciplinary open access archive for the deposit and dissemination of scientific research documents, whether they are published or not. The documents may come from teaching and research institutions in France or abroad, or from public or private research centers.
L'archive ouverte pluridisciplinaire HAL, est destinée au dépôt et à la diffusion de documents scientifiques de niveau recherche, publiés ou non, émanant des établissements d'enseignement et de recherche français ou étrangers, des laboratoires publics ou privés. 


\section{Detection of titanium nanoparticles in the hair shafts of a patient with frontal fibrosing alopecia}

\author{
Editor \\ Frontal fibrosing alopecia (FFA) is a lymphocyte-mediated pri- \\ mary cicatricial alopecia closely related to lichen planopilaris. ${ }^{1}$ \\ Over time, the number of FFA reports has increased continu- \\ ously, suggesting the implication of yet unidentified environ- \\ mental factors. Several studies based on questionnaires have \\ pointed out that leave-on facial skin care products, especially \\ sunscreens, could be implicated in FFA. ${ }^{2}$ Here, we report the \\ detection of titanium dioxide $\left(\mathrm{TiO}_{2}\right)$ along the hair shafts of a \\ patient presenting FFA.
}

The patient was a 73-year-old woman who presented with typical FFA characterized by a frontotemporal hairline regression and eyebrow loss (Fig. 1a, b). There was no manifestation of nail, mucosal or cutaneous lichen planus. A biopsy was per-formed in an active area of the temporal frontline, showing ostial hyperkeratosis and perifollicular fibrosis with gigantocellular reaction, as well as a reduced number of hair follicles. Her past medical history was unremarkable, but she reported the application on a daily basis of a sunscreen containing nanoparticles of $\mathrm{TiO}_{2}$ during the last ten years to prevent skin photoageing.

A physicochemical characterization of the patient's hair was performed with scanning electron microscopy (SEM) coupled with energy-dispersive X-ray spectroscopy (EDX). Two plucked hairs were analysed using SEM, which showed the presence of micrometre scale abnormal deposits on the hair surface (Fig. 1c, d). The EDX analysis of these deposits pointed out the presence of silicium, sulphur, chlorine, calcium and titanium (Fig. 1e, f). These findings are in line with the literature, ${ }^{3}$ except for the presence of titanium. In a second phase, a finer analysis of the particles containing titanium was performed with micro-X-ray fluorescence spectroscopy. This technique evidenced a large aggregate of 0.5 - to $1-\mu \mathrm{m}$-sized titanium particles associated with smaller $(<=0.5 \mu \mathrm{m})$ titanium particles on the hair surface. The EDX microanalysis confirmed the presence of a fluorescence peak corresponding to exogenous titanium in these abnormal deposits (Fig. 1g). The strong intensity of this peak (up to 200 counts/50 $\mathrm{ms})$ reflects a high concentration of titanium along the patient's hair shafts.

$\mathrm{TiO}_{2}$ is the most widely used white pigment in the world. It has a wide range of applications, from paint to food colouring, and is also used in cosmetics and skin care. Due to its properties of UV blocking, $\mathrm{TiO}_{2}$ is extensively used in sunscreens. The potential toxicity of $\mathrm{TiO} 2$ is an important public health concern as $\mathrm{TiO}_{2}$ is classified by the International Agency for Research on Cancer (IARC) as an IARC Group 2B carcinogen. Concerning the skin, it is still debated whether $\mathrm{TiO}_{2}$ does or not penetrate the stratum corneum, but it has been clearly demonstrated that it can deposit in the follicular orifice. ${ }^{4}$ To date, there are no available data concerning the impact of $\mathrm{TiO}_{2}$ cutaneous exposure on hair growth. However, the detection of $\mathrm{TiO}_{2}$ along the hair shafts of our patient raises the question of a possible implication of $\mathrm{TiO}_{2}$ in $\mathrm{FFA}$ pathogenesis via an allergic process. This hypothesis is based on the fact that lichen planus, which is a close or even the same entity as FFA, can be a consequence of metal sensitization, especially for oral lichen planus in association with dental implants containing nickel, iron or zinc. ${ }^{5}$ Moreover, there are several reports of contact dermatitis or granulomatous reactions induced by $\mathrm{TiO}_{2}$ upon its use in pacemakers, hip prostheses or osteosynthesis, showing that $\mathrm{TiO}_{2}$ can be a target allergen for T-cell lymphocytes. ${ }^{6}$ Further studies are needed to confirm this potential link.

\footnotetext{
F. Brunet-Possenti,,$^{1, *}$ L. Deschamps, ${ }^{2}$ H. Colboc, ${ }^{3}$ A. Somogyi, ${ }^{4}$ K. Medjoubi, ${ }^{4}$ D. Bazin, ${ }^{5}$ V. Descamps ${ }^{1}$ ${ }^{1}$ Department of Dermatology, Bichat Hospital, HUPNVS, AP-HP, Paris 7 University, Paris, France, ${ }^{2}$ Department of Pathology, Bichat Hospital, HUPNVS, AP-HP, Paris, France, ${ }^{3}$ Department of Dermatology, Rothschild Hospital, AP-HP, Paris, France, ${ }^{4}$ Synchrotron SOLEIL, Gif-sur-Yvette,

France, ${ }^{5}$ LCMCP-UPMC, College de France, Paris, France ${ }^{*}$ Correspondence: F. Brunet-Possenti. Email: forence.brunet-possenti @aphp.fr

\section{References}

1 Poblet E, Jiménez F, Pascual A, Piqué E. Frontal fibrosing alopecia versus lichen planopilaris: a clinicopathological study. Int J Dermatol 2006; 45: 375-380.

2 Debroy Kidambi A, Dobson K, Holmes S, et al. Frontal fibrosing alopecia in men: an association with facial moisturizers and sunscreens. Br J Dermatol 2017; 177: 260-261.

3 Majewska U, Banas D, Braziewicz J, et al. X-ray fluorescence techniques in medical applications: reference values of elements in human serum, urine and hair. ACTA Phys Pol Ser A 2014; 125: 864-868.

4 Lademann J, Weigmann H, Rickmeyer C, et al. Penetration of titanium dioxide microparticles in a sunscreen formulation into the horny layer and the follicular orifice. Skin Pharmacol Appl Skin Physiol 1999; 12: 247-256.

5 Tiwari SM, Gebauer K, Frydrych AM, Burrows S. Dental patch testing in patients with undifferentiated oral lichen planus. Australas J Dermatol 2017. https://doi.org/10.1111/ajd.12692. [Epub ahead of print].

6 Müller K, Valentine-Thon E. Hypersensitivity to titanium: clinical and laboratory evidence. Neuro Endocrinol Lett 2006; 27(Suppl 1): 31-35.
} 

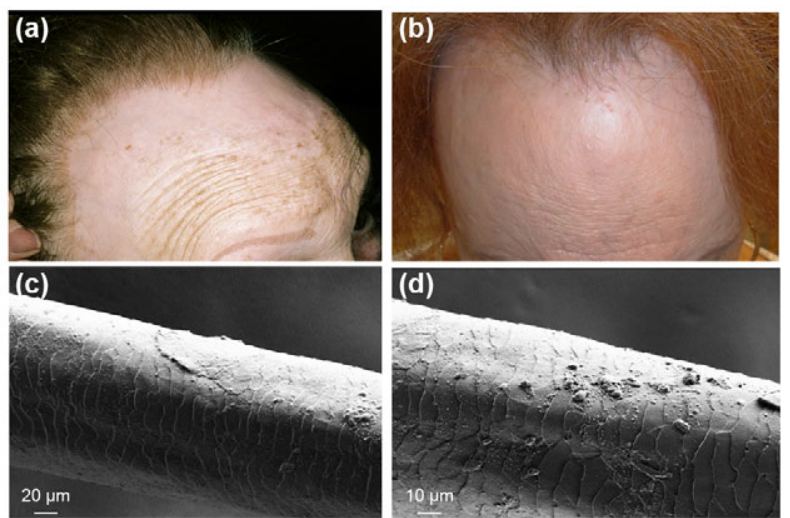

(e)
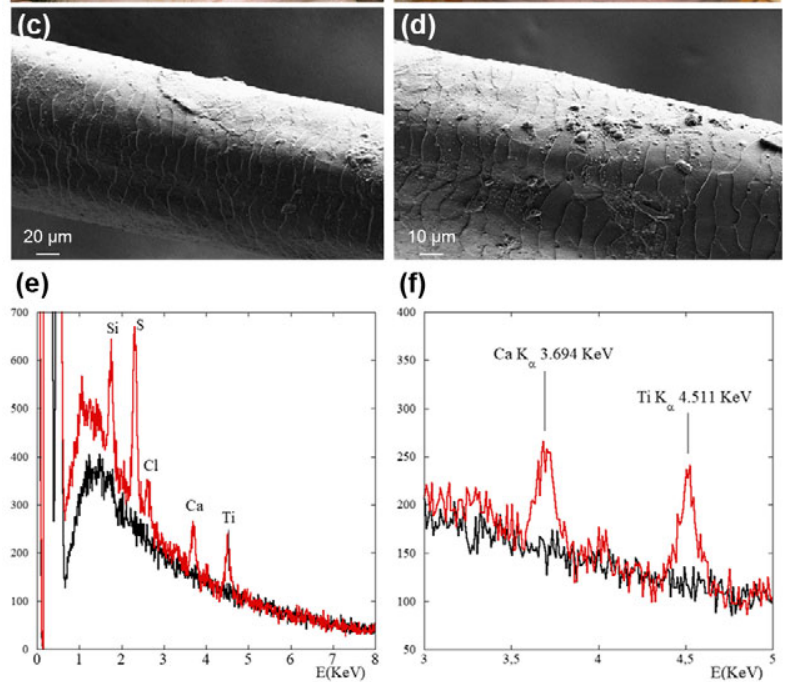

(f)

(g)

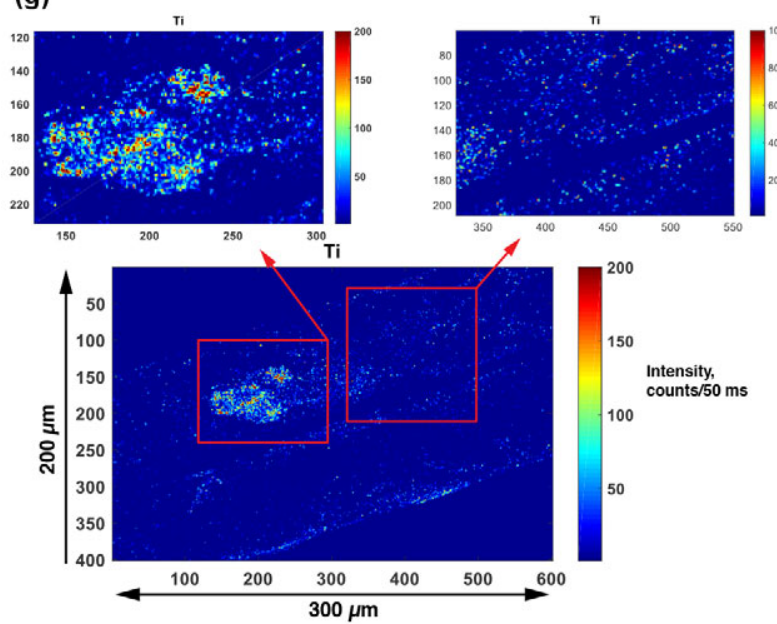

Figure 1 Clinical features and physicochemical analysis. Clinical features of the patient $(a, b)$. Typical frontal fibrosing alopecia characterized by a hairline regression (a) associated with eyebrows loss (b). (c, d) Conventional SEM images of a patient's plucked hair showing the presence of micrometre scale abnormal deposits, scale bar $20 \mu \mathrm{m}$ (c) and $10 \mu \mathrm{m}$ (d). (e, f) The EDX data (black support, red abnormal deposit) identify the presence of silicium $\left(\mathrm{EK}_{\alpha}=1.740 \mathrm{keV}\right)$, sulphur $\left(\mathrm{EK}_{\alpha}=2.305 \mathrm{keV}\right)$, chlorine $\left(\mathrm{EK}_{\alpha}=2.622 \mathrm{keV}\right)$, calcium $\left(\mathrm{EK}_{\alpha}=3.694 \mathrm{keV}\right)$ and titanium $(E K \alpha=4.511 \mathrm{keV})$ in the abnormal deposit present at the hair surface (g). Micro-X-ray fluorescence spectroscopy: high $500 \mathrm{~nm}$ resolution distribution maps of Ti within the two measured hair samples. 